\title{
Index to Volume 30, 2014
}

\author{
Contents of Volume 30, Numbers 1-4 \\ Articles, See Author Index \\ Book Reviews 163, 563, 567, 571 \\ Research Note 147 \\ Editorial Collaborators 859 \\ Erratum 167 \\ Index 865 \\ Prelude/Preface 171, 381, 575
}

\section{Author Index}

Aarts, K., See Haan, M.

Agans, R.P., Jefferson, M.T., Bowling, J.M., Zeng, D., Yang, J., and Silverbush, M. Enumerating the Hidden Homeless: Strategies to Estimate the Homeless Gone Missing From a

Point-in-Time Count . . . . . . . . . . . . . . . . . . . . . . . . . . . . . . . . . . . . . . . . . 215-229

Battle, D., See Stone, C.

Bavdaž, M., See Torres van Grinsven, V.

Beaumont, J-F., Bocci, C., and Haziza, D. An Adaptive Data Collection Procedure

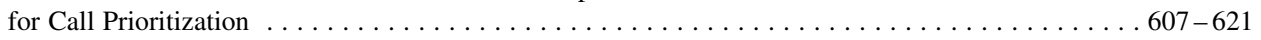

Beresovsky, V., See Lewis, T.

Bergdahl, H., See Biemer, P.

Bergdahl, H., See Biemer, P. Rejoinder

Biemer, P., Trewin, D., Bergdahl, H., and Japec, L. A System for Managing the Quality

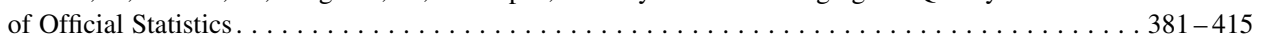

Biemer, P., Trewin, D., Bergdahl, H., and Japec, L. Rejoinder. . . . . . . . . . . . . . . . . . . . $437-442$

Bleninger, P., See Dreschler, J.

Bocci, C., See Beaumont, J.-F.

Bolko, I., See Torres van Grinsven, V.

Bowling, J.M., See Agans, R.P.

Burgard, J.P., Münnich, R.T. and Zimmermann, T. The Impact of Sampling Designs on Small Area

Estimates for Business Data . . . . . . . . . . . . . . . . . . . . . . . . . . . . . . . . . . 749-771

Buysse. A., See Dewaele, A.

Caen, M., See Dewaele, M.

Chipperfield, J.O. Disclosure-Protected Inference with Linked Microdata Using a Remote

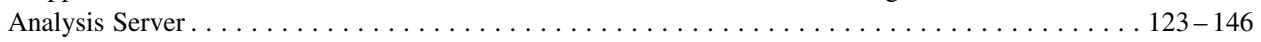

Cho, M., Eltinge, J.L., Gershunskaya, J., and Huff, L. Evaluation of Generalized Variance

Functions in the Analysis of Complex Survey Data . . . . . . . . . . . . . . . . . . . 63-90

Cho, M., Eltinge, J.L., Gershunskaya, J., Huff, L., and Wang, L. Analytic Tools for Evaluating

Variability of Standard Errors in Large-Scale Establishment Surveys . . . . . . . . . . . . . . . 787-810

Costa, A., Garciá, J., and Raymond J.L. Are All Quality Dimensions of Equal Importance when

Measuring the Perceived Quality of Official Statistics? Evidence from Spain . . . . . . . . . . . . $547-562$

Couper, M.P., See Das, M.

Das, M. and Couper, M.P. Optimizing Opt-Out Consent for Record Linkage . . . . . . . . . . . . . . 479-497

Day, C.D., See Kott, P.S.

Decker, S., See Lewis, T. 
D’Elia, E. Predictions vs. Preliminary Sample Estimates: The Case of Eurozone

Quarterly GDP . . . . . . . . . . . . . . . . . . . . . . . . . . . . . . . . . . 499-520

Dewaele, A., Caen, M., and Buysse, A. Comparing Survey and Sampling Methods for Reaching

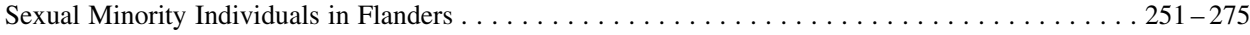

Dolson, D. Discussion . . . . . . . . . . . . . . . . . . . . . . . . . . . . . . . . . . . . . . . . . . . . . . . 421 -424

Dreschler, J., Ronning, G., and Bleninger, P. Disclosure Risk from Factor Scores. . . . . . . . . . . . 107 - 122

Earp, M., Mitchell, M., McCarthy, J., and Kreuter, F. Modeling Nonresponse in Establishment

Surveys: Using an Ensemble Tree Model to Create Nonresponse Propensity Scores and Detect

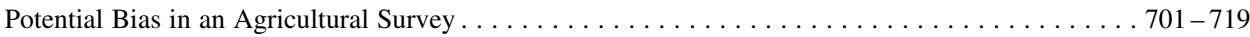

Dyer Yount, N., See Sigman, R.

Eckman, S., See Himelein, K.

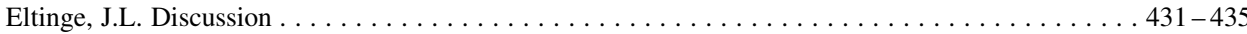

Eltinge, J.L., See Cho, M.

Elvers, E. Discussion . . . . . . . . . . . . . . . . . . . . . . . . . . . . . . . . . . . . . . . . . . . . . . . . $425-429$

English, N., See Willis, G.B.

Garciá, J., See Costa, A.

Gershunskaya, J., See Cho, M.

Goldberg, E., See Lewis, T.

Goldstein, H., See Lynn, P.

Gramlich, T., See Schnell, R.

Griffin, R.A. Potential Uses of Administrative Records for Triple System Modeling for Estimation of Census Coverage Error in $2020 \ldots \ldots \ldots \ldots \ldots \ldots \ldots$. . . . . . . . . . . . . . . . 177 - 189

Haan, M., Ongena Y.P., and Aarts, K. Reaching Hard-to-Survey Populations: Mode Choice

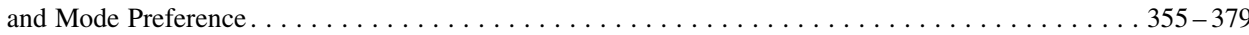

Haunberger, S. Item Nonresponse in Face-to-Face Interviews with Children. . . . . . . . . . . . . . 459 -477

Haziza, D., See Beaumont, J.-F.

Himelein, K., Eckman, S., and Murray, S. Sampling Nomads: A New Technique for Remote,

Hard-to-Reach, and Mobile Populations . . . . . . . . . . . . . . . . . . . . . . . . . . . . . . . . 191-213

Huff, L., See Cho, M.

Japec, L., See Biemer, P.

Japec, L., See Biemer, P. Rejoinder

Jefferson, M.T., See Agans, R.P.

Jäckle, A., See Lugtig, P.

Kaminska. O., See Lynn, P.

Kapteyn, A., See Schonlau, M.

Kaputa S.J., See Mulry M.H.

Kott, P.S. and Day, C.D. Developing Calibration Weights and Standard-Error Estimates for a

Survey of Drug-Related Emergency-Department Visits . . . . . . . . . . . . . . . . . . . . 521 - 532

Kreuter, F., See Earp, M.

Lee, K., See Sigman, R.

Lewis, T., See Sigman, R.

Lewis, T., Goldberg, E., Schenker, N., Beresovsky, V., Schappert, S., Decker, S., Sonnenfeld, N., and Shimizu, I. Research Note: The Relative Impacts of Design Effects and Multiple

Imputation on Variance Estimates: A Case Study with the 2008 National Ambulatory

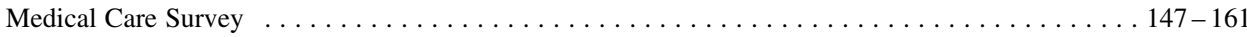

Lindblom, A. On Precision in Estimates of Change over Time where Samples are Positively

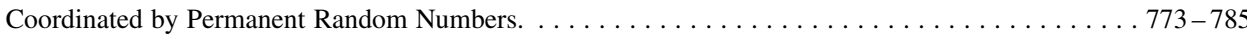

Loosveldt, G., See Vannieuwenhuyze, J.T.A.

Lugtig, P. and Jäckle, A. Can I just check ...? Effects of Edit Check Questions on Measurement Error

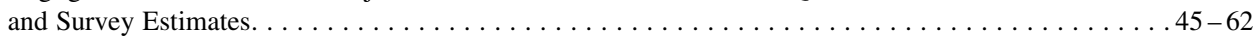

Lynn, P., Kaminska. O., and Goldstein, H. Panel Attrition: How Important is Interviewer

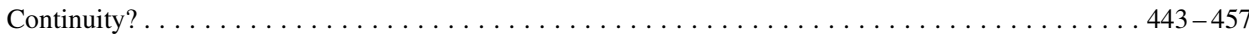

Maher, P., See Stone, C.

McCarthy, J., See Earp, M.

Mitchell, M., See Earp, M.

Molenberghs, G., See Vannieuwenhuyze, J.

Mulry, M.H., Oliver B.E., and Kaputa S.J. Detecting and Treating Verified Influential Values in

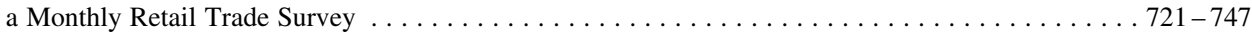


Münnich, R.T., See Burgard, J.P.

Murray, S., See Himelein, K.

Ogwang, T. A Convenient Method of Decomposing the Gini Index by Population Subgroups. . . . . $91-105$

Oliver B.E., See Mulry, M.H.

Ongena Y.P., See Haan, M.

Ouwehand, P. and Schouten B. Measuring Representativeness of Short Term Business

Statistics . . . . . . . . . . . . . . . . . . . . . . . . . . . . . . . . . . . . . . . . . . . . . . . . . . 623-649

Park, H. and Sha, M.M. Evaluating the Efficiency of Methods to Recruit Asian

Research Participants. . . . . . . . . . . . . . . . . . . . . . . . . . . . . . . $335-354$

Pedlow, S. A City-Based Design That Attempts to Improve National Representativeness

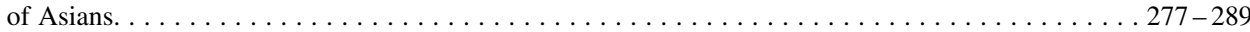

Pfeffermann. D. and Sverchkov, M. Estimation of Mean Squared Error of X-11-ARIMA and

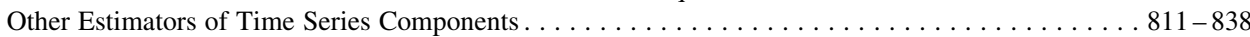

Raymond, J.L., See Costa, A.

Ritchie, F. Access to Sensitive Data: Satisfying Objectives Rather than Constrains . . . . . . . . . . . . 533-545

Robbins, M.W. The Utility of Nonparametric Transformations for Imputation of Survey Data . . . 675-700

Ronning, G., See Dreschler, J.

Schappert, S., See Lewis, T.

Schenker, N., See Lewis, T.

Scheuren, F., Discussion. . . . . . . . . . . . . . . . . . . . . . . . . . . . . . . . . . . . . 417-419

Schnell, R., Trappmann, M., and Gramlich, T. A Study of Assimilation Bias in Name-Based

Sampling of Migrants . . . . . . . . . . . . . . . . . . . . . . . . . . . . . . . . 231-249

Schonlau, M., Weidmer, B., and Kapteyn, A. Recruiting an Internet Panel Using

Respondent-Driven Sampling . . . . . . . . . . . . . . . . . . . . . . . . . . . . . . . . . . 291-310

Schouten, B., See Ouwehand, P.

Scott, L., See Stone, C.

Sha, M.M., See Park, H.

Shariff-Marco, S., See Willis, G.B.

Shimizu, I., See Lewis, T.

Sigman, R., Lewis, T., Dyer Yount, N., and Lee, K. Does the Length of Fielding Period Matter?

Examining Response Scores of Early Versus Late Responders. . . . . . . . . . . . . . . . . . . 651-674

Silverbush, M., See Agans, R.P.

Smith, T. W., See Willis, G.B.

Sonnenfeld, N., See Lewis, T.

Stone, C., Scott, L., Battle, D., and Maher, P. Locating Longitudinal Respondents

After a 50 -Year Hiatus. . . . . . . . . . . . . . . . . . . . . . . . . . . . . . . . . . . . . . . . . 311-334

Sverchkov, M., See Pfeffermann. D.

Tijdens, K. Dropout Rates and Response Times of an Occupation Search Tree in

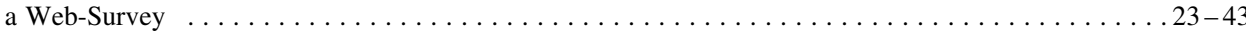

Torres van Grinsven, V., Bolko, I, and Bavdaž M. In Search of Motivation for the Business

Survey Response Task . . . . . . . . . . . . . . . . . . . . . . . . . . . . . . . . . . . . . . . . . . . . . 5 579-606

Toth, D. Data Smearing: An Approach to Disclosure Limitation for Tabular Data . . . . . . . . . . 839-857

Trappmann, M., See Schnell, R.

Trewin, See Biemer, P.

Trewin, See Biemer, P. Rejoinder.

Vannieuwenhuyze, J.T.A., Loosveldt, G., and Molenberghs, G. Evaluating Mode Effects in

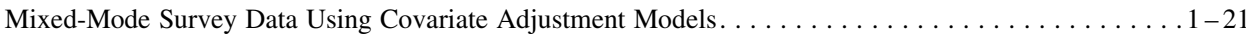

Weidmer, B., See Schonlau, M.

Willis, G.B., Smith, T. W., Shariff-Marco, S., English, N. Overview of the Special Issue on

Surveying the Hard-to-Reach . . . . . . . . . . . . . . . . . . . . . . . . . . . . . . . . . . . . . . $171-189$

Yang, J., See Agans, R.P.

Zeng, D., See Agans, R.P.

Zimmermann, T., See Burgard, J.P. 


\section{Book Reviews}

Question Evaluation Methods: Contributing to the Science of Data Quality

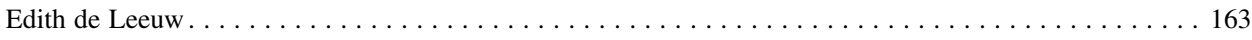

Synthetic Datasets for Statistical Disclosure Control, Theory and Implementation

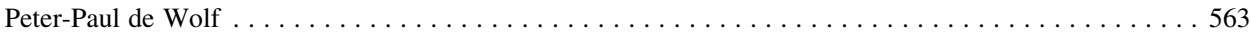

A Statistical Guide for the Ethically Perplexed

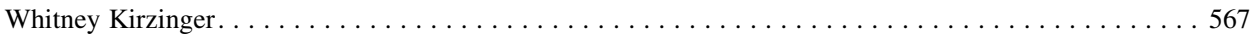

An Introduction to Model-Based Survey Sampling with Applications.

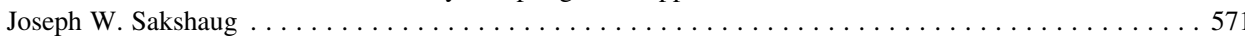

Printed in December 2014 